\title{
MEASURING THE EFFICIENCY OF BANKS: THE BOOTSTRAPPED I-DISTANCE GAR DEA APPROACH
}

\author{
Milan RADOJICIC ${ }^{\star}$, Gordana SAVIC, Veljko JEREMIC \\ Department of Operational Research and Statistics, Faculty of Organizational Science, \\ University of Belgrade, Jove Ilica 154, 11000 Belgrade, Serbia
}

Received 23 October 2017; accepted 24 April 2018

\begin{abstract}
The efficiency of the banking sector, particularly in developing countries, has captivated the attention of various researchers. Contributing to this issue, we present the results of in-depth analysis of the efficiency of Serbian banks during the period 2005-2016. Unlike previous papers evaluating the efficiency of South-Eastern European banks, we emphasize the importance of applying weight restrictions in Data Envelopment Analysis (DEA). The aim is to incorporate every aspect of a decision-making unit's performance to avoid misevaluation of a bank's efficiency. As a possible remedy to the issue, a bootstrapped I-distance is suggested as a statistically sound framework for determining weight bounds in the Global Assurance Region (GAR) DEA model. In terms of average efficiency, the banking sector of Serbia exhibits an improving trend over the period analyzed. The results show how banks can be evaluated when the impact of all the operating inputs and outputs are properly factored into the study.
\end{abstract}

Keywords: efficiency evaluation, data envelopment analysis, weight restriction, bootstrap, I-distance, banking, multivariate statistical methods.

JEL Classification: C14, C67, D24, G21.

\section{Introduction}

Efficiency in the banking sector has proved a compelling research area throughout the last decade (Aiello \& Bonanno, 2017; Delis, Iosifidi, \& Tsionas, 2017; Gofman, 2017; Kevork, Pange, Tzeremes, \& Tzeremes, 2017). Such measurements are usually made in order to investigate how a bank is performing in comparison to other banks on the same market (Tan, Floros, \& Anchor, 2017). They help the bank management identify shortcomings and improve business operations. Measuring efficiency is of particular importance to the banking sector of the developing and emerging economies (Davutyan \& Yildirim, 2017) since they have a significant cost efficiency gap compared to developed countries (Nurboja \& Košak, 2017).

${ }^{\star}$ Corresponding author. E-mail: milan.radojicic@fon.bg.ac.rs 
Throughout the years, many different methods for evaluating the efficiency of banks have been proposed. Besides stochastic frontier analysis (Huang, Lin, \& Chen, 2017; Psillaki \& Mamatzakis, 2017; Silva, Tabak, Cajueiro, \& Dias, 2017) and non-parametric local linear maximum likelihood (Tsionas \& Mamatzakis, 2017), Data Envelopment Analysis (DEA) has become the method most frequently used (Staub, Souza, \& Tabak 2010; Ray \& Das, 2010; Paradi \& Zhu, 2013; Färe, Grosskopf, Maudos, \& Tortosa-Ausina, 2015; Kumar, Charles, \& Mishra, 2016). Since 1978, when it was first introduced by Charnes, Cooper and Rhodes (1978), the DEA has been applied in more than 6500 publications (Liu, J. Y. Lu, V. M. Lu, 2016).

Berger and Humphrey (1997) performed a comparative review, which included more than 120 studies related to measuring the efficiency of financial institutions. It includes studies conducted in more than 20 countries with at least five major efficiency frontier measurement techniques. Later, Berger (2007) published research which included newer applications of frontier techniques applied to bank efficiency. A recent review of studies of bank efficiency measurement shows that DEA was used in over 75\% of them (Fethi \& Pasiouras, 2010).

DEA allows efficiency to be measured on the basis of multiple inputs and outputs criteria (Simar, 2007; Simar \& Zelenyuk, 2011), but it does not require any prior weighting of inputs and outputs in a frontier analysis (Thompson, Langemeier, C. T. Lee, E. Lee, \& Thrall, 1990). The advantage to this approach is that inefficient DMUs are estimated with the most favorable set of weights. This is compelling proof that inefficient DMUs are operating badly. On the other hand, the problem of unrealistic weight dispersion can still occur when some DMUs are rated efficient, since the input and output weights have extreme or zero values (Bal, Örkcü, \& Çelebioğlu, 2010). Different approaches to restricting weights are typically proposed as a possible remedy to this issue. One of the first and most important papers on weight restrictions in DEA was written by Allen, Athanassopoulos, Dyson, and Thanassoulis (1997). This paper offered a comprehensive overview of the development of weight restrictions in DEA and provided guidelines for future research in that area.

Cook and Zhu (2008) argued that the same bounds for weights should not be assigned to all DMUs, but should rather be different for a particular group of DMUs, so they proposed the CAR-DEA (Context-Dependent Assurance Regions in DEA) model. The idea was explained using the example of bank branch where they formed three groups of branches according to importance of the indicator "transaction time", based on the location of branches.

Podinovski (2005) set out to explain the economic meaning of weight restrictions. He evaluated weight bounds using production trade-offs between inputs and outputs. This approach is valid under both a constant and a variable return to scale. In his later work, he proved that for any weight restrictions, the optimal weights of the multiplier model show the DMU in the best light in comparison to the entire technology expanded by the weight restrictions (Podinovski, 2016).

It is evident that in both direct weight restrictions and virtual weight restrictions, the definition of boundaries represents a challenging task. Usually, these boundaries are formed subjectively, by appeal to expert opinion (Cvetkoska \& Savić, 2017). In this way, subjective evaluation has a significant impact on final efficiency assessment, which is better avoided (Mandic, Delibasic, Knezevic, \& Benkovic, 2017). Due to the lack of an adequate approach in defining weight bounds, many hybrid DEA models have emerged. 
A widespread case is the hybrid AHP (Analytical Hierarchy Process) DEA model (Shang \& Sueyoshi, 1995; Zhu, 1996; Seifert \& Zhu, 1998; Takamura \& Tone, 2003). Jain, A. Kumar, S. Kumar, and Chandra (2015) have put forward a GA-DEA model (GA - Genetic Algorithm) in cases where bounds are estimated by a larger number of experts. Mecit and Alp (2013) suggested the COR-DEA (Correlation DEA) model which generate bounds using correlation. Gonçalves, Almeida, Lins, and Samanez (2013) used CCA-DEA (CCA - Canonical correlation analysis) to avoid subjective evaluation of weight bounds from an expert.

This paper introduces a novel approach to generating weight restrictions in DEA. Our approach is based on a multivariate statistics I-distance method (Ivanovic, 1977). The restrictions for the ratios of particular virtual inputs/outputs to total virtual input/output, which will be used in a global assurance region (GAR) DEA (Cooper, Seiford, \& Tone, 2006) model, are generated with the bootstrapped I-distance method (Radojicic, Savic, Radovanovic, \& Jeremic, 2015). In any iteration of bootstrap, the importance (weight) of each input/output indicator is calculated. Previously, Radojicic et al. (2015) determined the range of proportion of virtual inputs/outputs by summing/subtracting the mean value of the bootstrapped weight with a $3 \mathrm{SD} / 6 \mathrm{SD}$ value (SD-Standard Deviation). However, the key issue that emerged is the facts that lower and upper bounds were not obtained in bootstrap iterations, but rather represent a projection using the mean value and standard deviation. As a possible remedy to this issue, we propose a more comprehensive approach - selecting the minimal and maximal value of the weight of each input/output obtained during the bootstrap I-distance procedure. This approach of implementing weight restrictions also ensures that every input and output will have some, albeit small impact on the relative efficiency evaluation of each DMU. Moreover, the proposed approach overcomes the issue of possible subjectivity in $a$ priori determination of weight restrictions.

The proposed approach combines bootstrapped I-distance with the GAR DEA method by incorporating a lower and an upper bound of bootstrapped I-distance weights as bounds of virtual inputs and outputs in the GAR DEA model. The proposed approach was used for the in-depth analysis of Serbian banking sector efficiency over the twelve-year period between 2005 and 2016. The results obtained will be compared with the results of the basic variable return to scale DEA model (Banker, Charnes, \& Cooper, 1984). The remainder of the paper is structured as follows. This section is followed by an overview of efficiency evaluation in the banking sector with special reference to the selection of inputs and outputs. Section 2 describes the proposed bootstrapped I-distance GAR DEA approach. In section 3, the data used in the analysis is presented. Section 4 presents the results. Finally, the last section outlines the key contributions of the paper and presents ideas for the future directions of study.

\section{Overview of efficiency evaluation in the banking sector}

Our paper contributes to the body of articles examining the efficiency of Serbian banks. One of the first articles which dealt with this issue was (Mihailović, Bulajić, \& Savić, 2009). These researchers ranked 41 banks which were operating on the Serbian market in 2005. Two methods were used - the DEA super-efficiency model (Andersen \& Petersen, 1993) and I-distance. The inputs were assets, capital and number of employees. Interest revenue 
and revenue before taxation were chosen as the outputs. Nine banks were found to be efficient. Savic, Radosavljevic, and Ilievski (2012) measured the efficiency of Serbian banks using Window DEA analysis. Two models were presented - one for profit efficiency (ML1) and one for operating efficiency (ML2) measurement. For the profit efficiency model, the inputs were interest expense and non-interest expenses, while the outputs were interest income and non-interest income. For the operating efficiency model, the inputs were the number of employees, fixed assets and intangible investments, capital and deposits, while outputs were granted loans and deposits, and non-interest income. Both models assumed input orientation and constant return to scale. They examined the performance of 28 banks during period 2005-2011. The super-efficiency DEA model was used to rank efficient banks. They found that in ML1 only two banks were efficient during the whole period, while in ML2 no banks were efficient during the entire period. Bulajic, Jeremic, Knezevic, and Zarkic-Joksimovic (2013) performed analysis on 27 banks which were operating on the Serbian banking market from 2006 to 2010. The inputs were sources, liquid assets, cash, portfolio and number of employees, and output were core net business income and net interest income. Using the DBA (Distance Based Analysis) methodology, they found that three banks were efficient in every year. The most recent study on Serbian bank efficiency was conducted by (Marković, Knežević, Brown, \& Dmitrović, 2015) and covers the period of 2007-2010. Assets, number of employees and equity were the inputs, while total revenue and earnings before tax were regarded as outputs. The study examined 33 banks, and only one bank found to be efficient during the entire period.

The first step in assessing efficiency is to determine which business indicators will be chosen as inputs and outputs. This selection directly affects the results of the analysis. There is no consensus among researchers on which indicators should be used. The various combinations of inputs and outputs which have been used in DEA for the efficiency measurement of banks are presented in Table 1.

Most controversies arise over the question of deposits. Some authors are of the opinion that deposits should be regarded as input (Barros, Chen, Liang, \& Peypoch, 2011; Asmild \& Matthews, 2012; Hou, Wang, Zhang, 2014) while others think that they should be seen as output (Devaney \& Weber, 2002; Staub et al., 2010). Consequently, two main approaches have been developed - the intermediation approach (regards deposits as input) and the production approach (regards deposit as output). The production approach regards banks as production units which use labor and capital to produce loans and deposit account services. According to this approach, banks aim to minimize the use of resources in providing products and services. The intermediation approach regards banks as a mediators between savers and investors. Banks serve to convert deposits into loans. In this approach the bank's main objective is to raise funds (deposits) to sell (loans) in order to maximize profit (Avkiran, 2006). Berger and Humphrey (1997) concluded that neither of these two approaches is perfect because neither is capable of encompassing fully the dual role of banks. Their standpoint is that while the production approach may be better for evaluating the efficiency of bank branches, the intermediation approach is more suitable for evaluating banking activity in its entirety. We have accepted the assumption that banks collect deposits to sell them in the form of loans, thus, in this paper, we opted for the intermediation approach. 
Table 1. A survey of DEA applications in the banking sector

\begin{tabular}{|c|c|c|c|c|}
\hline Paper & Scope & Inputs & Outputs & Methodology \\
\hline \begin{tabular}{|l|} 
(Ferrier \& \\
Hirschberg, 1997)
\end{tabular} & $\begin{array}{l}94 \text { banks in Italy, } \\
\text { in } 1986\end{array}$ & $\begin{array}{l}\text { number of } \\
\text { employees, } \\
\text { capital, consumer } \\
\text { deposit accounts, } \\
\text { commercial deposit } \\
\text { accounts, industrial } \\
\text { deposit accounts }\end{array}$ & $\begin{array}{l}\text { loans (consumer, } \\
\text { commercial } \\
\text { and industrial), } \\
\text { deposits at } \\
\text { other financial } \\
\text { institutions, } \\
\text { investments, } \\
\text { number of } \\
\text { branches }\end{array}$ & $\begin{array}{l}\text { DEA with } \\
\text { bootstrapped } \\
\text { confidence } \\
\text { intervals for } \\
\text { efficiency scores }\end{array}$ \\
\hline $\begin{array}{l}\text { (Kuosmanen \& } \\
\text { Post, 2001) }\end{array}$ & 453 EU banks & $\begin{array}{l}\text { equity capital, debt } \\
\text { capital, operational } \\
\text { costs }\end{array}$ & total earning assets & $\begin{array}{l}\text { weight } \\
\text { restricted DEA }\end{array}$ \\
\hline $\begin{array}{l}\text { (Isik \& Hassan, } \\
\text { 2002) }\end{array}$ & $\begin{array}{l}54 \text { banks in } \\
\text { Turkey, 1988- } \\
1996\end{array}$ & labor, capital, funds & $\begin{array}{l}\text { short-term loans, } \\
\text { long-term loans, } \\
\text { risk-adjusted } \\
\text { off-balance sheet } \\
\text { items, other } \\
\text { earning assets }\end{array}$ & DEA \\
\hline $\begin{array}{l}\text { (Fukuyama } \\
\text { \&Weber, 2002) }\end{array}$ & $\begin{array}{l}141 \text { banks in } \\
\text { Japan, } 1988-1996\end{array}$ & labor, capital, funds & $\begin{array}{l}\text { loans, other } \\
\text { investments }\end{array}$ & $\begin{array}{l}\text { Input and } \\
\text { output-oriented } \\
\text { DEA - } \\
\text { Malmquist } \\
\text { index }\end{array}$ \\
\hline $\begin{array}{l}\text { (Mukherjee, Nath, } \\
\text { \& Nath Pal, 2002) }\end{array}$ & $\begin{array}{l}68 \text { banks in India, } \\
1996-1999\end{array}$ & $\begin{array}{l}\text { net worth, } \\
\text { borrowings, } \\
\text { operating expenses, } \\
\text { number of } \\
\text { employees, number } \\
\text { of branches }\end{array}$ & $\begin{array}{l}\text { deposit, net profit, } \\
\text { advances, non- } \\
\text { interest income, } \\
\text { interest spread }\end{array}$ & $\begin{array}{l}\text { output oriented } \\
\text { CCR DEA }\end{array}$ \\
\hline (Kao \& Liu, 2004) & $\begin{array}{l}24 \text { banks in } \\
\text { Taiwan, 2009- } \\
2011\end{array}$ & $\begin{array}{l}\text { total deposits, } \\
\text { interest expenses, } \\
\text { non-interest } \\
\text { expenses }\end{array}$ & $\begin{array}{l}\text { total loans, interest } \\
\text { income, non- } \\
\text { interest income }\end{array}$ & CCR DEA \\
\hline $\begin{array}{l}\text { (Casu, } \\
\text { Girardone, \& } \\
\text { Molyneux, 2004) }\end{array}$ & $\begin{array}{l}50 \text { banks in } \\
\text { Europe, 1994- } \\
2000\end{array}$ & $\begin{array}{l}\text { the average cost } \\
\text { of labor, deposits, } \\
\text { capital }\end{array}$ & $\begin{array}{l}\text { total loans, } \\
\text { securities, the } \\
\text { nominal value of } \\
\text { banks' off-balance } \\
\text { sheet items }\end{array}$ & $\begin{array}{l}\text { DEA } \\
\text { Malmquist } \\
\text { index }\end{array}$ \\
\hline $\begin{array}{l}\text { (Paul \& } \\
\text { Kourouche, 2008) }\end{array}$ & $\begin{array}{l}10 \text { banks in } \\
\text { Australia, 1997- } \\
2005\end{array}$ & $\begin{array}{l}\text { interest expense, } \\
\text { non-interest expense }\end{array}$ & $\begin{array}{l}\text { net interest } \\
\text { income, non- } \\
\text { interest income }\end{array}$ & $\begin{array}{l}\text { input-oriented } \\
\text { DEA }\end{array}$ \\
\hline $\begin{array}{l}\text { (Tortosa-Ausina, } \\
\text { Grifell-Tatjé, } \\
\text { Armero, \& } \\
\text { Conesa, 2008) }\end{array}$ & $\begin{array}{l}50 \text { banks in Spain, } \\
1992-1998\end{array}$ & $\begin{array}{l}\text { labor, capital, } \\
\text { purchased funds }\end{array}$ & $\begin{array}{l}\text { loans, core } \\
\text { deposits, non- } \\
\text { interest income } \\
\text { and income from } \\
\text { securities }\end{array}$ & $\begin{array}{l}\text { Bootstrapped } \\
\text { efficiency score } \\
\text { in DEA }\end{array}$ \\
\hline
\end{tabular}


Continue of Table 1

\begin{tabular}{|c|c|c|c|c|}
\hline Paper & Scope & Inputs & Outputs & Methodology \\
\hline $\begin{array}{l}\text { (Sahoo \& Tone, } \\
\text { 2009) }\end{array}$ & $\begin{array}{l}78 \text { banks in India, } \\
1997-2001\end{array}$ & $\begin{array}{l}\text { fixed assets, } \\
\text { borrowed funds, } \\
\text { labor }\end{array}$ & $\begin{array}{l}\text { investments, } \\
\text { performing loan } \\
\text { assets, non-interest } \\
\text { income }\end{array}$ & DEA \\
\hline (Avkiran, 2009) & 15 banks in UAE & $\begin{array}{l}\text { interest expense, } \\
\text { non-interest expense }\end{array}$ & $\begin{array}{l}\text { interest income, } \\
\text { non-interest } \\
\text { income }\end{array}$ & Network DEA \\
\hline $\begin{array}{l}\text { (Thoraneenitiyan } \\
\text { \& Avkiran, 2009) }\end{array}$ & $\begin{array}{l}110 \text { banks in Asia, } \\
1997-2001\end{array}$ & $\begin{array}{l}\text { deposits, labor } \\
\text { capital, physical } \\
\text { capital }\end{array}$ & $\begin{array}{l}\text { amount of loans, } \\
\text { investments and } \\
\text { other earning } \\
\text { assets, fee income, } \\
\text { off-balance sheet } \\
\text { items } \\
\end{array}$ & $\begin{array}{l}\text { Integrating } \\
\text { DEA and SFA }\end{array}$ \\
\hline $\begin{array}{l}\text { (Staub et al., } \\
2010)\end{array}$ & $\begin{array}{l}127 \text { banks in } \\
\text { Brasil, 2000-2007 }\end{array}$ & $\begin{array}{l}\text { labor, capital, other } \\
\text { assets }\end{array}$ & $\begin{array}{l}\text { deposit, loans, } \\
\text { investment }\end{array}$ & DEA \\
\hline (Savic et al., 2012) & $\begin{array}{l}28 \text { banks in } \\
\text { Serbia, 2005-2011 }\end{array}$ & $\begin{array}{l}\text { number of } \\
\text { employees, fixed } \\
\text { assets and intangible } \\
\text { investments, capital } \\
\text { deposits }\end{array}$ & $\begin{array}{l}\text { granted loans and } \\
\text { deposits, non- } \\
\text { interest income }\end{array}$ & $\begin{array}{l}\text { Input oriented } \\
\text { CCR DEA } \\
\text { model }\end{array}$ \\
\hline $\begin{array}{l}\text { (Jayaraman, } \\
\text { Srinivasan, \& } \\
\text { Jeremic, 2013) }\end{array}$ & $\begin{array}{l}34 \text { banks in India, } \\
2005-2012\end{array}$ & $\begin{array}{l}\text { equity, borrowed } \\
\text { funds, number of } \\
\text { employees, number } \\
\text { of branches }\end{array}$ & $\begin{array}{l}\text { deployed funds, } \\
\text { non-interest } \\
\text { income }\end{array}$ & $\begin{array}{l}\text { Comparison } \\
\text { between DEA } \\
\text { and DBA } \\
\text { (Distance Based } \\
\text { Analysis) } \\
\end{array}$ \\
\hline $\begin{array}{l}\text { (Puri \& Yadav, } \\
\text { 2013) }\end{array}$ & $\begin{array}{l}17 \text { banks in India, } \\
2010\end{array}$ & $\begin{array}{l}\text { labor, fixed assets, } \\
\text { total expenses }\end{array}$ & $\begin{array}{l}\text { interest income, } \\
\text { other income }\end{array}$ & fuzzy DEA \\
\hline $\begin{array}{l}\text { (Moradi-Motlagh } \\
\text { \& Saleh, 2014) }\end{array}$ & $\begin{array}{l}10 \text { banks in } \\
\text { Australia, during } \\
1997-2005\end{array}$ & $\begin{array}{l}\text { interest expense, } \\
\text { non-interest expense }\end{array}$ & $\begin{array}{l}\text { interest income, } \\
\text { non-interest } \\
\text { income }\end{array}$ & $\begin{array}{l}\text { DEA with } \\
\text { bootstrapped } \\
\text { confidence } \\
\text { intervals for } \\
\text { efficiency scores } \\
\end{array}$ \\
\hline (Hou et al., 2014) & $\begin{array}{l}44 \text { major banks in } \\
\text { China, 2007-2011 }\end{array}$ & $\begin{array}{l}\text { deposits, fixed } \\
\text { assets, number of } \\
\text { employees }\end{array}$ & $\begin{array}{l}\text { the total net loan, } \\
\text { other earning } \\
\text { assets }\end{array}$ & $\begin{array}{l}\text { two-stage, } \\
\text { semi- } \\
\text { parametric } \\
\text { DEA model } \\
\end{array}$ \\
\hline 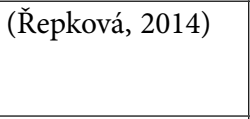 & $\begin{array}{l}11 \text { banks in the } \\
\text { Czech Republic, } \\
\text { 2003-2012 }\end{array}$ & labor, deposits & $\begin{array}{l}\text { loans, net interest } \\
\text { income }\end{array}$ & $\begin{array}{l}\text { Input oriented } \\
\text { BCC and CCR } \\
\text { DEA models } \\
\end{array}$ \\
\hline (Kao \& Liu, 2014) & $\begin{array}{l}22 \text { banks in } \\
\text { Taiwan, 2009- } \\
2011\end{array}$ & $\begin{array}{l}\text { labor, physical } \\
\text { capital, purchased } \\
\text { funds }\end{array}$ & $\begin{array}{l}\text { demand deposits, } \\
\text { short-term loans, } \\
\text { medium-and-long- } \\
\text { term loans }\end{array}$ & $\begin{array}{l}\text { DEA model for } \\
\text { multi-period } \\
\text { efficiency }\end{array}$ \\
\hline $\begin{array}{l}\text { (Johnes, Izzeldin, } \\
\text { \& Pappas, 2014) }\end{array}$ & $\begin{array}{l}\text { Islamic banks } \\
\text { in } 18 \text { countries, } \\
2004-2009\end{array}$ & $\begin{array}{l}\text { deposits and short- } \\
\text { term funding, fixed } \\
\text { assets, general and } \\
\text { administrative } \\
\text { expenses, equity }\end{array}$ & $\begin{array}{l}\text { total loans, other } \\
\text { earning assets }\end{array}$ & $\begin{array}{l}\text { output oriented } \\
\text { CCR DEA } \\
\text { model }\end{array}$ \\
\hline
\end{tabular}


End of Table 1

\begin{tabular}{|c|c|c|c|c|}
\hline Paper & Scope & Inputs & Outputs & Methodology \\
\hline $\begin{array}{l}\text { (D. Tandon, } \\
\text { K. Tandon, \& } \\
\text { Malhotra, 2014) }\end{array}$ & $\begin{array}{l}44 \text { banks in India, } \\
2009-2012\end{array}$ & deposits, assets & $\begin{array}{l}\text { interest income, } \\
\text { non-interest } \\
\text { income }\end{array}$ & $\begin{array}{l}\text { output oriented } \\
\text { CCR and BCC } \\
\text { DEA }\end{array}$ \\
\hline $\begin{array}{l}\text { (C. R. Chiu, Y. } \\
\text { H. Chiu, Fang, \& } \\
\text { Pang, 2014) }\end{array}$ & $\begin{array}{l}23 \text { banks in } \\
\text { Taiwan } 2008\end{array}$ & $\begin{array}{l}\text { number of } \\
\text { employees, assets, } \\
\text { equity }\end{array}$ & $\begin{array}{l}\text { operating profit, } \\
\text { non-performing } \\
\text { loans }\end{array}$ & $\begin{array}{l}\text { A context- } \\
\text { dependent } \\
\text { range-adjusted } \\
\text { measure DEA } \\
\text { model }\end{array}$ \\
\hline $\begin{array}{l}\text { (Marković et al., } \\
\text { 2015) }\end{array}$ & $\begin{array}{l}33 \text { banks in } \\
\text { Serbia, 2007-2010 }\end{array}$ & $\begin{array}{l}\text { assets, equity, } \\
\text { number of } \\
\text { employees }\end{array}$ & $\begin{array}{l}\text { earnings before } \\
\text { tax, total revenue }\end{array}$ & $\begin{array}{l}\text { Input oriented } \\
\text { CCR DEA } \\
\text { model - } \\
\text { Malmquist } \\
\text { index }\end{array}$ \\
\hline (Avkiran, 2015) & $\begin{array}{l}49 \text { banks in } \\
\text { China, 2008-2010 }\end{array}$ & $\begin{array}{l}\text { interest expenses on } \\
\text { customer deposit, } \\
\text { other interest } \\
\text { expenses, personnel } \\
\text { expenses, other } \\
\text { operating expenses }\end{array}$ & $\begin{array}{l}\text { interest income } \\
\text { on loans, other } \\
\text { interest income, } \\
\text { bet fees and } \\
\text { commissions, } \\
\text { other operating } \\
\text { income }\end{array}$ & $\begin{array}{l}\text { dynamic } \\
\text { network DEA }\end{array}$ \\
\hline (Kao \& Liu, 2016) & $\begin{array}{l}22 \text { banks in } \\
\text { Taiwan, 2008- } \\
2013\end{array}$ & $\begin{array}{l}\text { labor, physical } \\
\text { capital, purchased } \\
\text { funds }\end{array}$ & $\begin{array}{l}\text { demand deposits, } \\
\text { short-term loans, } \\
\text { medium-and-long- } \\
\text { term loans }\end{array}$ & $\begin{array}{l}\text { DEA - } \\
\text { Malmquist } \\
\text { index }\end{array}$ \\
\hline $\begin{array}{l}\text { (Fukuyama \& } \\
\text { Matousek, 2017) }\end{array}$ & $\begin{array}{l}72 \text { banks in Japan, } \\
2000-2013\end{array}$ & $\begin{array}{l}\text { number of } \\
\text { employees, capital }\end{array}$ & loans, securities & $\begin{array}{l}\text { two-stage } \\
\text { network DEA } \\
\text { model }\end{array}$ \\
\hline $\begin{array}{l}\text { (Tanna, Luo, \& } \\
\text { De Vita, 2017) }\end{array}$ & $\begin{array}{l}1530 \text { banks from } \\
88 \text { countries, } \\
1999-2011\end{array}$ & $\begin{array}{l}\text { fixed assets, deposit } \\
\text { and short-term } \\
\text { funding, personnel } \\
\text { expenses }\end{array}$ & $\begin{array}{l}\text { loans, other } \\
\text { earning assets, } \\
\text { non-interest } \\
\text { income }\end{array}$ & $\begin{array}{l}\text { DEA and } \\
\text { total factor } \\
\text { productivity }\end{array}$ \\
\hline $\begin{array}{l}\text { (Simper, Hall, } \\
\text { Liu, Zelenyuk, \& } \\
\text { Zhou, 2017) }\end{array}$ & $\begin{array}{l}272 \text { banks in } \\
\text { South Korea, } \\
2007-2011\end{array}$ & $\begin{array}{l}\text { general admin and } \\
\text { other expenses, } \\
\text { fee and trading } \\
\text { expenditure, loan } \\
\text { loss provisions, } \\
\text { equity }\end{array}$ & $\begin{array}{l}\text { non-performing } \\
\text { loans, net interest } \\
\text { revenue, other } \\
\text { operating revenue }\end{array}$ & $\begin{array}{l}\text { BCC DEA } \\
\text { model }\end{array}$ \\
\hline $\begin{array}{l}\text { (Fukuyama \& } \\
\text { Webber, 2017) }\end{array}$ & $\begin{array}{l}100 \text { banks in } \\
\text { Japan, 2007-2012 }\end{array}$ & $\begin{array}{l}\text { labor, physical } \\
\text { capital, equity capital }\end{array}$ & $\begin{array}{l}\text { performing } \\
\text { loans, securities } \\
\text { investments }\end{array}$ & $\begin{array}{l}\text { dynamic } \\
\text { network DEA }\end{array}$ \\
\hline $\begin{array}{l}\text { (Kevork et al., } \\
\text { 2017) }\end{array}$ & $\begin{array}{l}644 \text { banks from } \\
28 \text { European } \\
\text { countries, in 2007, } \\
2010 \text { and } 2014\end{array}$ & $\begin{array}{l}\text { total assets, the } \\
\text { total number of } \\
\text { employees, total } \\
\text { deposits }\end{array}$ & $\begin{array}{l}\text { net loans, } \\
\text { securities } \\
\text { investments }\end{array}$ & $\begin{array}{l}\text { directional } \\
\text { distance } \\
\text { function with } \\
\text { DEA }\end{array}$ \\
\hline (Silva et al., 2017) & $\begin{array}{l}65 \text { banks in } \\
\text { China, 2001-2012 }\end{array}$ & $\begin{array}{l}\text { total interest } \\
\text { expenses, total non- } \\
\text { interest expenses }\end{array}$ & $\begin{array}{l}\text { deposits, loans, } \\
\text { liquid assets }\end{array}$ & $\begin{array}{l}\text { Comparison } \\
\text { between DEA } \\
\text { and SFA }\end{array}$ \\
\hline
\end{tabular}




\section{Methodology}

The bootstrapping method has recently been used in bank efficiency measurement with DEA (Hou et al., 2014; Stewart, Matousek, \& Nguyen, 2016; Moradi-Motlagh \& Saleh, 2014; N. Zelenyuk, V. Zelenyuk, 2014; Alhassan \& Tetteh, 2017), but the bootstrap was applied to the DEA efficiency scores (Le, Harvie, \& Arjomandi, 2017). All these papers rely on works elaborated by Simar and Wilson $(1998,2007)$. The methodology proposed in our paper is based on the bootstrapped I-distance method used for setting lower and upper bounds in GAR DEA models (Yu, 2012; Galagedera, 2014). The fundamentals of both methods, Idistance and DEA, are given in this section.

\subsection{Bootstrapped I-distance}

The I-distance metric (Ivanovic, 1977) easily finds a solution to the problem of incorporating various indicators of different measurement units into a single synthetic indicator (Jeremic et al., 2012). Since it can overcome issues of subjectivity in a composite indicator, the Idistance method is frequently used as the aggregation method (Jeremic, Bulajic, Martic, \& Radojicic, 2011). The method itself has considerable benefits; among others, it excludes the duplicity of information. The construction of the I-distance is an iterative process, which uses the concept of total discriminant effect (Jayaraman et al., 2013).

Let $X^{T}=\left(X_{1}, X_{2}, \ldots X_{k}\right)$ be a set of indicators chosen to characterize the entities. Idistance between two entities $e_{r}=\left(x_{1 r}, x_{2 r}, \ldots x_{k r}\right)$ and $e_{s}=\left(x_{1 s}, x_{2 s}, \ldots x_{k s}\right)$ is defined as

$$
D(r, s)=\sum_{i=1}^{k} \frac{\left|d_{i}(r, s)\right|}{\sigma_{i}} \prod_{j=1}^{i-1}\left(1-r_{j i .12 \ldots j-1}\right),
$$

where $d_{i}(r, s)$ is the discriminative effect, the distance between the values of variable $X_{i}$ for $e_{r}$ and $e_{s}$

$$
d_{i}(r, s)=x_{i r}-x_{i s}, i \in\{1, \ldots, k\} \text {, }
$$

$\sigma_{i}$ is the standard deviation of $X_{i}$ and $r_{j i .12 \ldots j-1}$ is the partial correlation coefficient between $X_{i}$ and $X_{j},(j<i)$ (Dobrota, Bulajic, Bornmann, \& Jeremic, 2016).

In addition, a frequently used square I-distance provides additional benefits (Išljamović, Jeremić, Petrović, \& Radojičić, 2015). It is given as:

$$
D^{2}(r, s)=\sum_{i=1}^{k} \frac{d_{i}^{2}(r, s)}{\sigma_{i}^{2}} \prod_{j=1}^{i-1}\left(1-r_{j i .12 \ldots j-1}^{2}\right) .
$$

The next phase in obtaining I-distance weights is to calculate the Pearson correlation between I-distance values and input/output indicators. Weights are formed by calculating the ratios of the Pearson correlation and the sum of correlations for all inputs/outputs:

$$
w_{i}=\frac{r_{i}}{\sum_{i=1}^{k} r_{i}},
$$

where $r_{i}(i=1, \ldots k)$ is a Pearson correlation between the $i$-th input/output variable and the I-distance value (Dobrota, Martic, Bulajic, \& Jeremic, 2015). 
Efron (1979) was the first to introduce the bootstrap method. It is a statistical computerintensive approach that can provide statistic measures for a broad range of problems (Davison \& Hinkley, 1997). Bootstrap is based on the idea of resampling from the original sample of data. The statistics of interest are recalculated on the basis of each sample, and the resulting "bootstrapped" measures are then used to construct a sampling distribution for the statistics of interest (Ferrier \& Hirschberg, 1997).

This paper proposes using a bootstrap procedure for the I-distance method. Using a bootstrapped I-distance approach, the set of weights $w_{i}(i=1,2 \ldots, k)$ assigned to individual indicators $X^{T}=\left(X_{1}, X_{2}, \ldots X_{k}\right)$ by calculating their lower $\left(L_{i}\right)$ and upper bounds $\left(U_{i}\right)$, are obtained.

The procedure for bootstrapped I-distance is as follows:

1. From the initial number of $n$ entities, a random sample $S_{s}(s=1, \ldots, m)$ of size $l(l<n)$ is taken, and then calculation of I-distance is performed on that sample and values for I-distance weights $w_{i}$ are obtained;

2. This process is repeated $m$ times (usually $m$ is no fewer than 1,000 times), and for each random bootstrapped sample $S_{s}$, I-distance weights are obtained;

3. The lower $\left(L_{i}\right)$ bound for $i$-th variable (input/output) is determined by a minimum and the upper bound $\left(U_{i}\right)$ by a maximum of all obtained I-distance weights $w_{i}(i=1,2 \ldots, k)$, from $m$ iterations.

The results of a bootstrapped I-distance method will be used in the next step of efficiency evaluation using DEA.

\subsection{Data Envelopment Analysis - DEA}

The DEA has been used for efficiency appraisal in a broad range of areas over the last 40 years (Liu, L.Y. Lu, W. M. Lu, \& Lin, 2013; Emrouznejad, Banker, Lopes, \& de Almeida, 2014; Emrouznejad \& Yang, 2018; Scalzer, Rodrigues, Macedo, \& Wanke, 2018). It was introduced by Charnes, Cooper and Rhodes (1978) assuming a constant return to scale. Suppose that $\mathrm{DMU}_{j}(j=1, \ldots, n)$ uses inputs $x_{i j}(i=1, \ldots, m)$ to produce outputs $y_{r j}(r=1, . ., s)$. The multiplier output-oriented DEA model is as follows:

$$
\begin{aligned}
(\min ) h_{k}= & \sum_{i=1}^{m} v_{i} x_{i k} \\
\text { s.t. } & \\
& \sum_{r=1}^{s} \mu_{r} y_{r j}=1 ; \\
& \sum_{i=1}^{m} v_{i} x_{i j}-\sum_{r=1}^{s} \mu_{r} y_{r j} \geq 0, j=1, \ldots, n ; \\
& \mu_{r} \geq \varepsilon, \quad r=1, \ldots, s ; \\
& v_{i} \geq \varepsilon, \quad i=1, \ldots, m .
\end{aligned}
$$

where $h_{k}$ is a measure of the relative efficiency of $\mathrm{DMU}_{k}, \mu_{r}$ is the weight assigned to output $r, v_{i}$ is the weight assigned to input $i$, and $\varepsilon$ is a small positive non-Archimedean value. Model 
(5) is an output-oriented model with constant return to scale (CRS). By adding the free sign variable $u^{*}$ to the objective function and second constraints, the model (5) becomes an output-oriented model DEA model with a variable return to scale (VRS) (Banker et al., 1984).

\subsubsection{DEA model with weight restrictions}

The weight restriction is a common modification of multiplier models, implemented as the incorporation of additional inequalities on the input and output weights. The weight restrictions are helpful in practical applications since their use can significantly improve the efficiency discrimination of DEA models (Allen et al., 1997). Thompson, Singleton Jr, Thrall, and Smith (1986) were among the first to proposed weights restriction to differentiate between efficient units, while Dyson and Thanassoulis (1988), considered that restricting weights is important to avoid ignoring of some inputs or outputs.

One of the approaches of restricting weights is total weight restriction. This approach prevents some of the inputs and outputs from being over emphasized or ignored in the efficiency assessment. The constraint has the following form:

$$
L_{i} \leq v_{i} \leq U_{i}, \quad i=1, \ldots, m .
$$

Values $L_{i}$ and $U_{i}$ are given by experts. The main difficulty in applying this type of weights restriction is in defining those lower and upper bounds since they can lead to an infeasible solution.

Other approaches to direct weight restrictions (Thompson et al., 1990) are based on the relationship between:

- Input-input or output-output weights - Assurance Region of type I (ARI) (Thompson et al., 1986; Zhu, 1996; Taylor, Thompson, Thrall, \& Dharmapala, 1997);

- Input-output weights - Assurance Region of type II (ARII) (Thanassoulis, Boussofiane, \& Dyson, 1995).

Wong and Beasley (1990) have proposed a model in which, instead of restricting actual weights, virtual input and output are restricted. This would help avoid the problem of sensitivity to the unit of measurement for inputs and outputs which occur in direct weight restriction models since virtual input/output is dimensionless. The virtual input and output of a DMU shows the relative contribution of every input and output to its efficiency. The higher the value of virtual input/output, the more significant that input/output is in evaluating the efficiency of a particular DMU (Sarrico \& Dyson, 2004). The proposed constraint has the following form:

$$
L_{i} \leq \frac{v_{i} x_{i j}}{\sum_{i=1}^{m} v_{i} x_{i j}} \leq U_{i}, i=1, \ldots, m, j=1, \ldots, n
$$

under the condition that $0 \leq L_{i} \leq U_{i} \leq 1, i=1, \ldots, m$. Similar restrictions can be applied to outputs. The lower and upper bounds can be imposed subjectively based on expert opinion under the conditions $\sum_{i=1}^{m} L_{i} \leq 1$ and $\sum_{i=1}^{m} U_{i} \geq 1$ if all inputs (outputs) are restricted. DEA models which have included these constraints are also known in literature as the GAR-DEA model (Yu, 2012; Galagedera, 2014). 


\subsection{Bootstrapped I-distance DEA methodology}

As already mentioned, basic DEA models allow flexible weights determination, but this feature can lead to misevaluation of DMUs because input and output weights may have extreme or zero values. This paper suggests a statistically founded approach to determining the bounds of virtual input/output proportion (7). The main idea is to investigate the range of weight of the particular input or output which is common for all the DMUs under evaluation, based on existing data. The bootstrapped I-distance procedure, described in section 2.1., is used in the first step of the suggested procedure for this purpose. The procedure provides the range of weights which covers the whole set of DMUs. The obtained values are always in the range from 0 to 1 which corresponds to virtual inputs or outputs in DEA efficiency evaluation. DEA efficiency is measured afterwards using the presented model (5) with the integration of weights restriction (7). Therefore, the bootstrapped I-distance DEA procedure put forward in order to avoid subjective judgment in setting lower and upper bounds is as follows:

1. Lower and upper bounds calculation based on bootstrapped I-distance procedure given in chapter 2.1.;

2. Solving GAR DEA model (5), (7) with a constant or variable return to scale assumption;

3. Analyzing the results and comparing them to those obtained by the basic DEA models.

This procedure is used for the efficiency evaluation of banks in Serbia based on panel data for the period 2005-2016.

\section{Data}

The data utilized in this paper were captured from Income Statements and Balance Sheets, available on National Bank of Serbia (NBS) database (see http://www.nbs.rs). The dataset consists of a balanced panel of 25 banks covering a period of twelve years - from 2005 to 2016.

The choice of the inputs and outputs has been guided by choices made in previous studies (Table 2) and data availability. As we opted for measuring the efficiency of the whole bank, not just the branches of the bank, the intermediation approach was used, as explained in section 1. Thus, deposits are regarded as inputs. In addition to deposits (I4), we included three more inputs - personnel expenses (I1), fixed assets (I2), and capital (I3). For outputs, we

Table 2. Top 5 inputs and outputs used in DEA studies of banks (from Table 1)

\begin{tabular}{|l|c|l|c|}
\hline \multicolumn{1}{|c|}{ Inputs } & \# Studies & \multicolumn{1}{c|}{ Outputs } & \# Studies \\
\hline labor/personnel expenses & 14 & loans & 17 \\
\hline capital & 10 & non-interest income & 10 \\
\hline deposits & 10 & other placements/ earning assets & 7 \\
\hline fixed assets & 10 & investments & 7 \\
\hline number of employees & 8 & interest income & 6 \\
\hline
\end{tabular}


employed loans (O1), other placements (O2), and non-interest income (O3). This decision is also consistent with other studies of the Serbian banking industry. Table 3 shows descriptive statistics of inputs and outputs over the whole observed period.

The inter-correlation test of all inputs and all outputs shows that the isotonicity test (Avkiran, 1999) was passed (Pearson correlations $>0.30 ; \alpha=0.01$ ). These results indicate that increasing amounts of inputs lead to increasing of outputs. The rule of thumb $m+s \leq n / 3$, where $m$ is the number of inputs, $s$ is the number of outputs and $n$ is the number of entities (Cooper et al., 2006), is also satisfied $(7<25 / 3)$. Validation of the model therefore proved that input and output selection had been performed correctly.

The DEA analysis was conducted using DEA Solver software (Cooper et al., 2006), and weights were generated using in-house developed I-distance software.

Table 3. Descriptive statistics of indicators

\begin{tabular}{|l|c|c|c|c|c|c|c|}
\hline \multicolumn{1}{|c|}{ Statistic } & I1 & I2 & I3 & I4 & O1 & O2 & O3 \\
\hline Mean & 1,694 & 2,320 & 12,660 & 41,871 & 50,313 & 10,403 & 2,205 \\
\hline Median & 1,328 & 1,412 & 10,164 & 24,647 & 31,171 & 2,917 & 1,391 \\
\hline Max & 7,574 & 12,345 & 41,760 & 255,449 & 271,750 & 136,124 & 16,190 \\
\hline Min & 114 & 68 & 202 & 512 & 114 & 21 & 81 \\
\hline St.Dev. & 1,322 & 2,309 & 10,299 & 46,630 & 54,619 & 18,926 & 2,343 \\
\hline
\end{tabular}

Note: all values are presented in RSD millions (Serbian dinar).

\section{Empirical findings and results}

Even though the banks are homogeneous from the standpoint of structure and goals, and are operating in the same country under the same circumstances, and in spite of the fact that the data used is drawn from a balanced dataset, their size differs from small to very large. Consequently, we compared the efficiency of each bank for each year, assuming a variable return to scale. This method allows the bank under evaluation to be compared with those which operate on a similar scale of economy and at similar market strength. The results of the efficiency measurement are discussed below.

\subsection{Pure technical efficiency evaluation}

The dataset consists of 25 banks of various sizes, i.e. the capital varies from 202 to 41,760 million RSD. Therefore, we opted for the VRS DEA model which allows for variable returns to scale and compared units of different sizes. The first assessment of pure technical intermediation efficiency was performed using an output-oriented VRS DEA model. An overview of the results is presented in Table 4.

Table 4 shows that banks in Serbia are mainly considered efficient in the period 20052016. ( 0.869 to 0.940$)$. The results given per year indicate that at least 11 banks are assessed as efficient. The lowest average efficiency of $86.9 \%$ with 11 banks operating below the efficiency frontier was obtained for 2010. The highest number of efficient banks (17 out of 24) was obtained in 2005, 2008 and 2013. Three banks were estimated to be efficient in each year. 
Table 4. Average efficiency of banks estimated by VRS DEA model

\begin{tabular}{|l|c|c|c|c|c|c|}
\hline \multicolumn{1}{|c|}{ Year } & 2005 & 2006 & 2007 & 2008 & 2009 & 2010 \\
\hline Average score & 0.934 & 0.872 & 0.940 & 0.920 & 0.894 & 0.869 \\
\hline \# efficient DMUs & 17 & 15 & 16 & 17 & 16 & 14 \\
\hline \# inefficient DMUs & 8 & 10 & 9 & 8 & 9 & 11 \\
\hline \multicolumn{1}{|c|}{ Year } & 2011 & 2012 & 2013 & 2014 & 2015 & 2016 \\
\hline Average score & 0.878 & 0.890 & 0.903 & 0.894 & 0.891 & 0.900 \\
\hline \# efficient DMUs & 16 & 15 & 17 & 14 & 11 & 13 \\
\hline \# inefficient DMUs & 9 & 10 & 8 & 11 & 14 & 12 \\
\hline
\end{tabular}

\subsection{Weight restricted DEA efficiency evaluation}

The first-stage analysis shows that the average efficiency of all DMUs, obtained by the VRS DEA model tends to be very high, with more DMUs assessed as efficient than inefficient. This occurred because of the total weight flexibility and the freedom of DMUs to choose the best combinations of input and outputs. Table 5 summarizes the number of zero weights assigned to inputs and outputs. Obviously, the most ignored inputs and outputs are personnel expenses (I1), fixed assets (I2) and the output "other placements" (O2) over the observed period. This freedom of choosing only desirable inputs and/or outputs favors the banks that use more resources for producing the same level of outputs. On the other hand, they are also ignored by most of the banks in almost all the years of the observed period.

To avoid the assignment of zero weights to the inputs or outputs of DMUs, the GAR DEA output-oriented model with a variable return to scale $(5,7)$ was applied. The lower and upper bounds were generated as bootstrapped I-distance weights. The examples of the

Table 5. Number of zero weights assigned to inputs and outputs

\begin{tabular}{|c|c|c|c|c|c|c|c|c|}
\hline \multirow{2}{*}{ Year } & \multirow{2}{*}{ \# DMUs } & \multicolumn{5}{|c|}{ Inputs } & \multicolumn{3}{c|}{ Outputs } \\
\cline { 3 - 9 } & & I1 & I2 & I3 & I & O1 & O2 & O3 \\
\hline 2005 & 25 & 17 & 18 & 10 & 4 & 5 & 8 & 14 \\
\hline 2006 & 25 & 16 & 17 & 6 & 10 & 7 & 20 & 17 \\
\hline 2007 & 25 & 18 & 15 & 6 & 10 & 2 & 17 & 18 \\
\hline 2008 & 25 & 16 & 13 & 4 & 12 & 1 & 12 & 9 \\
\hline 2009 & 25 & 13 & 17 & 8 & 9 & 3 & 15 & 14 \\
\hline 2010 & 25 & 13 & 18 & 8 & 8 & 4 & 19 & 13 \\
\hline 2011 & 25 & 13 & 11 & 10 & 14 & 5 & 16 & 12 \\
\hline 2012 & 25 & 7 & 16 & 17 & 13 & 6 & 17 & 7 \\
\hline 2013 & 25 & 8 & 17 & 12 & 12 & 4 & 18 & 8 \\
\hline 2014 & 25 & 11 & 20 & 13 & 11 & 7 & 15 & 18 \\
\hline 2015 & 25 & 15 & 13 & 14 & 7 & 10 & 19 & 6 \\
\hline 2016 & 25 & 11 & 13 & 11 & 12 & 4 & 21 & 8 \\
\hline
\end{tabular}


I-distance weights obtained after 10,000 iterations of bootstrapping on $72 \%$ of the sample (18 banks in every iteration) are presented in Table 6 . The lower bound $(L)$ in the GAR model is determined by the minimum, while the upper bound $(U)$ is determined by the maximum obtained I-distance weight.

Table 6. Weights generated using the bootstrapped I-distance method

\begin{tabular}{|c|c|c|c|c|c|c|c|c|c|c|c|c|}
\hline & \multicolumn{4}{|c|}{2005} & \multicolumn{4}{|c|}{2006} & \multicolumn{4}{|c|}{2007} \\
\hline & $\mathrm{L}$ & $\mathrm{U}$ & $\mathrm{m}$ & $\sigma$ & $\mathrm{L}$ & $\mathrm{U}$ & $\mathrm{m}$ & $\sigma$ & $\mathrm{L}$ & $\mathrm{U}$ & $\mathrm{m}$ & $\sigma$ \\
\hline I1 & 0.22 & 0.32 & 0.28 & 0.01 & 0.25 & 0.32 & 0.29 & 0.01 & 0.25 & 0.32 & 0.28 & 0.01 \\
\hline $\mathrm{I} 2$ & 0.18 & 0.33 & 0.27 & 0.01 & 0.14 & 0.30 & 0.24 & 0.02 & 0.14 & 0.29 & 0.23 & 0.02 \\
\hline I3 & 0.17 & 0.31 & 0.22 & 0.01 & 0.15 & 0.28 & 0.20 & 0.01 & 0.18 & 0.28 & 0.22 & 0.01 \\
\hline $\mathrm{I} 4$ & 0.15 & 0.31 & 0.23 & 0.01 & 0.22 & 0.32 & 0.26 & 0.01 & 0.22 & 0.33 & 0.28 & 0.01 \\
\hline O1 & 0.27 & 0.41 & 0.35 & 0.03 & 0.27 & 0.40 & 0.34 & 0.03 & 0.26 & 0.40 & 0.34 & 0.02 \\
\hline $\mathrm{O} 2$ & 0.27 & 0.39 & 0.33 & 0.02 & 0.27 & 0.39 & 0.33 & 0.02 & 0.23 & 0.38 & 0.29 & 0.02 \\
\hline \multirow[t]{3}{*}{ O3 } & 0.28 & 0.39 & 0.32 & 0.01 & 0.28 & 0.41 & 0.33 & 0.03 & 0.31 & 0.41 & 0.37 & 0.02 \\
\hline & \multicolumn{4}{|c|}{2008} & \multicolumn{4}{|c|}{2009} & \multicolumn{4}{|c|}{2010} \\
\hline & $\mathrm{L}$ & $\mathrm{U}$ & $\mathrm{m}$ & $\sigma$ & $\mathrm{L}$ & $\mathrm{U}$ & $\mathrm{m}$ & $\sigma$ & $\mathrm{L}$ & $\mathrm{U}$ & $\mathrm{m}$ & $\sigma$ \\
\hline I1 & 0.21 & 0.29 & 0.25 & 0.01 & 0.19 & 0.29 & 0.25 & 0.01 & 0.18 & 0.29 & 0.24 & 0.01 \\
\hline $\mathrm{I} 2$ & 0.19 & 0.29 & 0.25 & 0.01 & 0.21 & 0.30 & 0.25 & 0.01 & 0.20 & 0.32 & 0.25 & 0.01 \\
\hline I3 & 0.18 & 0.28 & 0.22 & 0.02 & 0.17 & 0.28 & 0.22 & 0.01 & 0.20 & 0.28 & 0.23 & 0.01 \\
\hline $\mathrm{I} 4$ & 0.25 & 0.30 & 0.28 & 0.01 & 0.23 & 0.31 & 0.28 & 0.01 & 0.24 & 0.30 & 0.28 & 0.01 \\
\hline $\mathrm{O} 1$ & 0.28 & 0.40 & 0.36 & 0.02 & 0.28 & 0.41 & 0.37 & 0.02 & 0.26 & 0.37 & 0.33 & 0.02 \\
\hline $\mathrm{O} 2$ & 0.25 & 0.38 & 0.29 & 0.02 & 0.26 & 0.40 & 0.31 & 0.02 & 0.29 & 0.40 & 0.33 & 0.03 \\
\hline \multirow[t]{3}{*}{ O3 } & 0.30 & 0.42 & 0.35 & 0.02 & 0.27 & 0.38 & 0.32 & 0.01 & 0.29 & 0.40 & 0.34 & 0.01 \\
\hline & \multicolumn{4}{|c|}{2011} & \multicolumn{4}{|c|}{2012} & \multicolumn{4}{|c|}{2013} \\
\hline & $\mathrm{L}$ & $\bar{U}$ & $\mathrm{~m}$ & $\sigma$ & $\mathrm{L}$ & $\bar{U}$ & $\mathrm{~m}$ & $\sigma$ & $\mathrm{L}$ & $\mathrm{U}$ & $\mathrm{m}$ & $\sigma$ \\
\hline I1 & 0.14 & 0.29 & 0.24 & 0.02 & 0.15 & 0.29 & 0.24 & 0.02 & 0.15 & 0.29 & 0.23 & 0.01 \\
\hline $\mathrm{I} 2$ & 0.22 & 0.32 & 0.24 & 0.01 & 0.21 & 0.30 & 0.24 & 0.01 & 0.22 & 0.31 & 0.24 & 0.01 \\
\hline I3 & 0.18 & 0.29 & 0.23 & 0.01 & 0.19 & 0.28 & 0.25 & 0.01 & 0.19 & 0.28 & 0.24 & 0.01 \\
\hline I4 & 0.24 & 0.31 & 0.29 & 0.01 & 0.21 & 0.32 & 0.28 & 0.01 & 0.24 & 0.32 & 0.28 & 0.01 \\
\hline O1 & 0.26 & 0.40 & 0.35 & 0.01 & 0.28 & 0.38 & 0.34 & 0.01 & 0.26 & 0.37 & 0.35 & 0.01 \\
\hline $\mathrm{O} 2$ & 0.27 & 0.38 & 0.31 & 0.02 & 0.27 & 0.40 & 0.33 & 0.02 & 0.27 & 0.40 & 0.32 & 0.03 \\
\hline \multirow[t]{3}{*}{$\mathrm{O} 3$} & 0.27 & 0.41 & 0.34 & 0.01 & 0.28 & 0.38 & 0.33 & 0.02 & 0.27 & 0.39 & 0.34 & 0.01 \\
\hline & \multicolumn{4}{|c|}{2014} & \multicolumn{4}{|c|}{2015} & \multicolumn{4}{|c|}{2016} \\
\hline & $\mathrm{L}$ & $\mathrm{U}$ & $\mathrm{m}$ & $\sigma$ & $\mathrm{L}$ & $\mathrm{U}$ & $\mathrm{m}$ & $\sigma$ & $\mathrm{L}$ & $\mathrm{U}$ & $\mathrm{m}$ & $\sigma$ \\
\hline I1 & 0.16 & 0.29 & 0.24 & 0.01 & 0.13 & 0.29 & 0.24 & 0.02 & 0.13 & 0.28 & 0.24 & 0.02 \\
\hline $\mathrm{I} 2$ & 0.20 & 0.29 & 0.24 & 0.01 & 0.21 & 0.35 & 0.24 & 0.01 & 0.20 & 0.35 & 0.23 & 0.02 \\
\hline I3 & 0.21 & 0.27 & 0.24 & 0.01 & 0.21 & 0.27 & 0.24 & 0.01 & 0.21 & 0.23 & 0.24 & 0.01 \\
\hline I4 & 0.27 & 0.31 & 0.29 & 0.01 & 0.25 & 0.31 & 0.28 & 0.01 & 0.26 & 0.30 & 0.28 & 0.01 \\
\hline $\mathrm{O} 1$ & 0.25 & 0.36 & 0.33 & 0.02 & 0.21 & 0.35 & 0.32 & 0.02 & 0.18 & 0.34 & 0.31 & 0.02 \\
\hline $\mathrm{O} 2$ & 0.28 & 0.40 & 0.32 & 0.03 & 0.30 & 0.40 & 0.33 & 0.03 & 0.31 & 0.40 & 0.34 & 0.02 \\
\hline $\mathrm{O} 3$ & 0.27 & 0.40 & 0.35 & 0.02 & 0.27 & 0.41 & 0.35 & 0.02 & 0.29 & 0.41 & 0.35 & 0.01 \\
\hline
\end{tabular}

Note: m-mean; $\sigma$-standard deviation. 
Mean values of I-distance weights from Table 6 represent what should be the importance of indicators in efficiency measurement. Table 6 shows that the importance of the variable "deposits" has an increasing trend while the importance of variable "personnel expenses" has a declining trend.

The virtual input/output constraints (7) for one year are as follows:

$$
\begin{aligned}
& L_{I 1} \leq \frac{v_{I 1} x_{I 1 k}}{v_{I 1} x_{I 1 k}+v_{I 2} x_{I 2 k}+v_{I 3} x_{I 3 k}+v_{I 4} x_{I 4 k}} \leq U_{I 1} ; \\
& L_{I 2} \leq \frac{v_{I 2} x_{I 2 k}}{v_{I 1} x_{I 1 k}+v_{I 2} x_{I 2 k}+v_{I 3} x_{I 3 k}+v_{I 4} x_{I 4 k}} \leq U_{I 2} ; \\
& L_{I 3}+L_{I 4} \leq \frac{v_{I 3} x_{I 3 k}+v_{I 4} x_{I 4 k}}{v_{I 1} x_{I 1 k}+v_{I 2} x_{I 2 k}+v_{I 3} x_{I 3 k}+v_{I 4} x_{I 4 k}} \leq U_{I 3}+U_{I 4} ; \\
& L_{O 1}+L_{O 2} \leq \frac{u_{O 1} x_{O 1 k}+u_{O 2} x_{O 2 k}}{u_{O 1} x_{O 1 k}+u_{O 2} x_{O 2 k}+u_{O 3} x_{O 3 k}} \leq U_{O 1}+U_{O 2} ; \\
& L_{O 3} \leq \frac{u_{O 3} x_{O 3 k}}{u_{O 1} x_{O 1 k}+u_{O 2} x_{O 2 k}+u_{O 3} x_{O 3 k}} \leq U_{O 3} .
\end{aligned}
$$

The third and fourth constraints are modified to provide more flexibility in efficiency evaluation and allow banks to use at least one, preferably input (I3 (capital) and/or I4 (deposits)) and one of the outputs (O1 (loans) and/or O2 (other placements)). This means that a DMU will not be obligated to use all of its inputs and outputs in order to evaluate its efficiency. Only personnel expenses (I1), fixed assets (I2) and non-interest income (O3) are mandatory for all DMUs. Capital is considered complementary with deposits because the main source of funds could vary between different banks. For example, banks which are co-owned by the state predominantly use capital as a principal source of funds, while purely commercial banks must gather deposits in order to sell them in the form of loans. It is similar with loans and other placements. Some banks find their primary source of profit in other placements rather than in selling loans.

Table 7 shows that with the introduction of weight restrictions the situation has changed considerably. The overall efficiency of banks in Serbia, obtained by using the bootstrapped I-distance GAR DEA model, is $57.6 \%$ for the $2005-2016$ period. That is $32.3 \%$ lower than the overall efficiency shown by the basic VRS DEA model. The highest average efficiency was in 2010 (67\%), with nine banks estimated as efficient. The lowest average efficiency score was in $2006(45.1 \%)$ and with four banks on the efficiency frontier contrary to the results obtained by the VRS DEA model. The lowest average efficiency score is measured in 2010, while the highest is measured in 2007.

KBC Bank had the lowest efficiency score $(0.5 \%)$ in 2013. The highest average efficiency score was obtained for Banca Intesa $-98 \%$ and the bank was estimated as efficient in every year except in 2005 and 2015. Five banks were below the efficiency frontier over the observed period. None of the banks proved efficient in every year of analysis. The lowest average efficiency score (19.1\%) was observed for Findomestic Bank, contrary to its very good rank according to the VRS DEA model results.

There were only two efficient banks in 2015 - Postanska stedionica and Unicredit. The other banks which were efficient during the period prior to 2015 were below the efficiency 


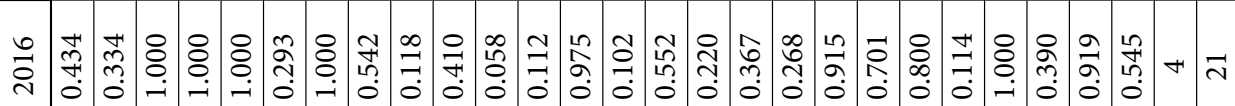

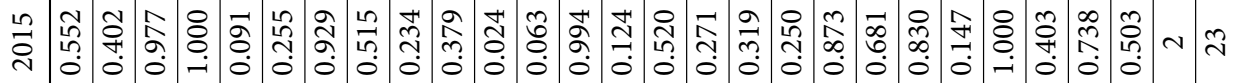

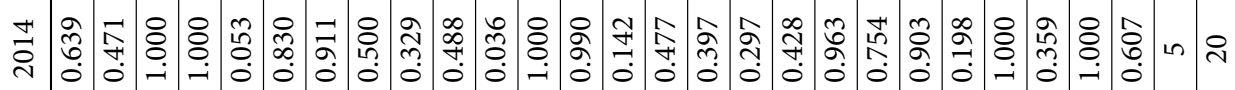

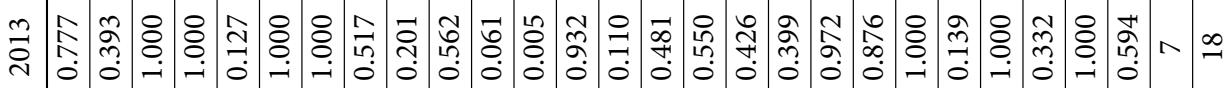

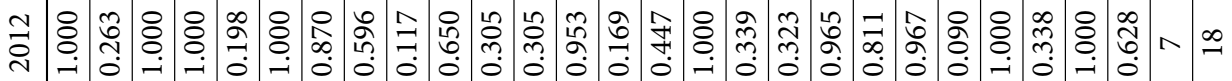

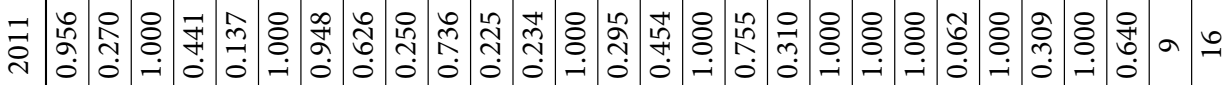

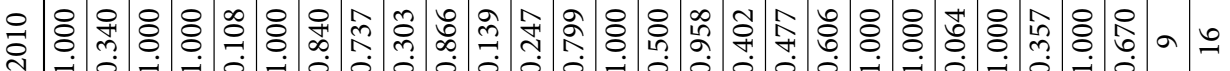

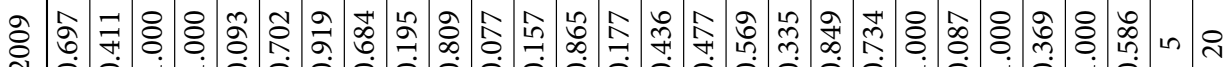

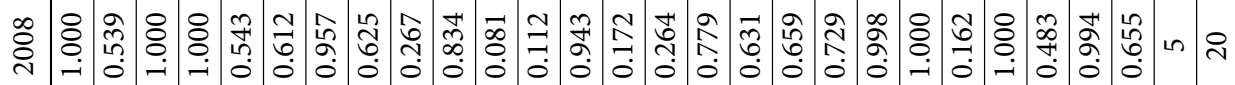

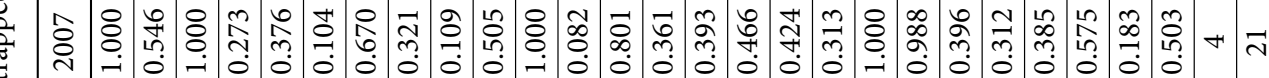

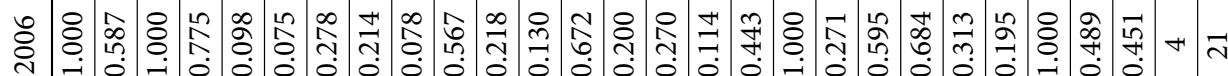

ت

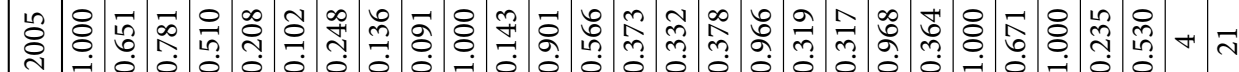

氖

.

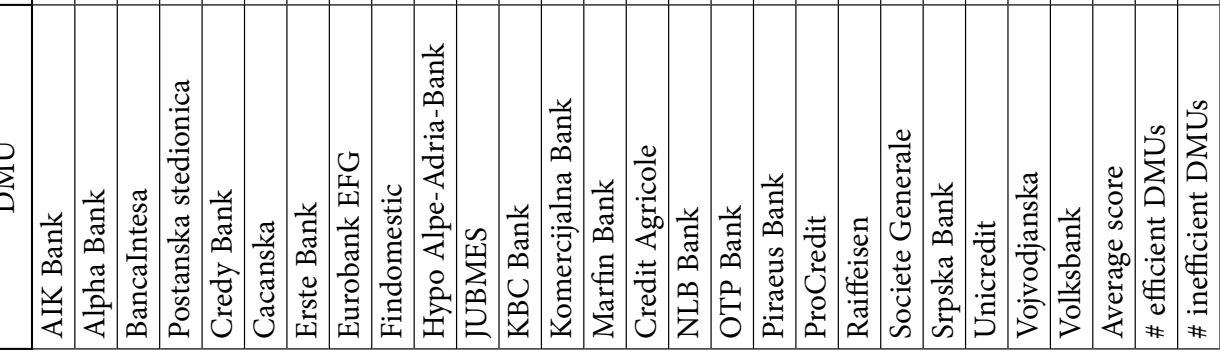


frontier in that year. The main reason for the overall inefficiency of the Serbian market during that year was the Greek bailout referendum. There are a number of Greek-owned banks operating in Serbia, and this is what caused the turbulence. Consumers were afraid of the collapse of those banks and started to withdraw their deposits, transferring them to other banks. Since we consider deposits as an input, this led to a situation where some banks increased their inputs, but at the same time did not manage to increase outputs, because there was lower demand for new loans. In contrast, the banks which had lower inputs due to the withdrawal of deposits, had to reduce the sale of loans because they lacked the funds.

Erste Bank exhibits a poor score in the first three years, followed by a period of growth, until 2013 when it started to operate on the efficiency frontier. Similar findings regarding Erste bank were made by (Savic et al., 2012). The reasons for the poor score in first two years lie in personnel expenses which were much higher in that year than in others. This is probably due to a change in a bank's majority shareholder. Before 2005, Erste Bank was predominantly owned by the state. Presumably, the bank management had to cut losses which led to downsizing, and consequently, severance payments increased personnel expenses. This is not just the case for Erste Bank. For every bank that went through a privatization process, there is a noticeable increase in efficiency.

A large increase in efficiency in 2016 for Credy bank stands out. Its average score during 2005-2015 was $18.5 \%$, but in 2016 Credy bank operated on the efficiency frontier. This result should be interpreted in light of the fact that Credy bank changed its ownership status twice after 2012. The bank reduced its fixed assets more than 15 times during that period, while at the same time they increased other placements (reaching a peak in 2016, where they were more than double than in 2015). The results from 2016 show that the bank is on the right path of development and that it should continue its business operations modelled on recent years.

In contrast to Credy bank, Cacanska may be an example of how a change of ownership structure can cause a drastic decrease in efficiency. After the first five analyzed years when it was constantly below the efficiency frontier, Cacanska finally consolidated, and in 2010 it was efficient. The bank was efficient in the following four years, and then in 2015, when it was privatized, Cacanska started to operate again below the efficiency frontier.

It is important to emphasize that it would be wrong to compare the average efficiency of the Serbian market through years because they are measured relative to the different frontiers. It is known that the year 2008 was the year of the global financial crisis (GFC), but if we were to concluded, on the basis of an average efficiency of $65.5 \%$, that the GFC did not affect the Serbian banking sector, we would be in danger of reaching an unsupported conclusion. The average efficiency score of $65.5 \%$ simply indicates that in that year, there may have been less variability between the banks. If we intended to examine the impact of the GFC, it would be necessary to conduct an additional study.

According to the results shown in Table 7, we can argue that Unicredit, Volksbank, Postanska stedionica and Societe Generale were prepared for the GFC, or responded effectively and took advantage of it, because from 2008 all four banks started to operate on the efficiency frontier in following years.

As stated, by using the weight restricted DEA model, the number of banks identified as efficient is reduced. Therefore, it is more evident which banks can be identified as market 
leaders. For the senior management of these banks, this is a good indicator that their business model is having the desired effects. Likewise, top managers at the banks which fail to achieve full efficiency have information on what aspects of their business need to improve if they are to become more competitive.

Another product of this study is the valuable information it offers regulatory bodies such as National Bank of Serbia, the Republic's central bank. The NBS is responsible for maintaining price stability and the stability of the financial system in general. Improved tools for monitoring bank efficiency, will allow the NBS more precise insight into the business operations of their banking sector and may contribute to the earlier detection of stress, thus allowing more timely and effective response.

\section{Conclusions}

The primary objective in evaluating the efficiency of banks is to see how particular actors are operating in relation to others on the same market. The results can help management identify weaknesses and improve overall business operations. This paper employs the bootstrapped I-distance GAR DEA approach to evaluate the efficiency of 25 banks operating in Serbia from 2005 to 2016 . This is the first time bootstrapped I-distance weights have been used as DEA constraints. The paper also emphasizes the importance of restricting weights flexibility in classical DEA models. By implementing weight restrictions, we avoided the assignment of zero weights to the inputs and outputs of any DMUs so that every input and output had an impact on the final efficiency evaluation. This makes the bootstrapped I-distance GAR DEA approach more informative than competing methods. The Pearson correlation between the I-distance values and input/output indicators provides objective weight restriction by considering the inputs/outputs relationship. The methodology presented in this paper has potential applications in other fields of interest where efficiency measurement is called for.

Perhaps the main limitation of the paper is that the research covers only one market and a relatively small number of DMUs. Another limitation is that this kind of analysis does not allow comparison of the efficiency of the Serbian banking sector as a whole, over a period of years, because they are measured relative to the different frontier.

The paper applies the intermediation approach to measuring bank efficiency. Consequently, the results describe the banks as business entities which aim principally to maximize profit by collecting deposits and selling them in the form of loans. The study offers useful insight into the efficiency of South-Eastern European banks. On the basis of the analysis over a twelve year period, it was possible to detect the bank's reaction to the turbulence caused by both the GFC and the Greek bailout referendum. The period prior to the financial crisis (2006-2008) was one of growth and investment in the Serbian banking sector, but the financial crisis caused changes in this trend and a slight fluctuation in pure technical efficiency.

Our findings reveal that, with the introduction of weight restrictions into a DEA model with a variable return to scale, the assessment of overall average efficiency fell by more than $30 \%$. This indicates that the results obtained with such weights restrictions are both more realistic and more comparable, and the model is properly calibrated, since the number of relatively efficient units is less than $50 \%$ (4 out of 25 in 2016). 
Further avenues of research suggest themselves, for example evaluation of changes in efficiency and technical progress using the Malmquist DEA index and bootstrapped I-distance method. Another direction would be to consult bank management on use of the variable and the utility of the results from a practical perspective (Eskelinen, 2017). Finally, the production approach to bank efficiency evaluation should also be included in future work, in order to determine whether and to what extent the results are influenced by the selection of output metric (Berger \& Humphrey, 1997).

\section{Acknowlegdments}

The authors gratefully thank the Deputy Editor-in Chief and the anonymous referees for their valuable comments and suggestions which have improved the paper.

\section{References}

Aiello, F., \& Bonanno, G. (2017). On the sources of heterogeneity in banking efficiency literature. Journal of Economic Surveys, 32(1), 194-225. https://doi.org/10.1111/joes.12193

Alhassan, A. L., \& Tetteh, M. L. (2017). Non-Interest Income and Bank Efficiency in Ghana: a two-stage DEA bootstrapping approach. Journal of African Business, 18(1), 124-142. https://doi.org/10.1080/15228916.2016.1227668

Allen, R., Athanassopoulos, A., Dyson, R. G., \& Thanassoulis, E. (1997). Weights restrictions and value judgements in data envelopment analysis: evolution, development and future directions. Annals of Operations Research, 73, 13-34. https://doi.org/10.1023/A:1018968909638

Andersen, P., \& Petersen, N. C. (1993). A procedure for ranking efficient units in data envelopment analysis. Management science, 39(10), 1261-1264. https://doi.org/10.1287/mnsc.39.10.1261

Asmild, M., \& Matthews, K. (2012). Multi-directional efficiency analysis of efficiency patterns in Chinese banks 1997-2008. European Journal of Operational Research, 219(2), 434-441. https://doi.org/10.1016/j.ejor.2012.01.001

Avkiran, N. K. (1999). An application reference for data envelopment analysis in branch banking: helping the novice researcher. International Journal of Bank Marketing, 17(5), 206-220. https://doi.org/10.1108/02652329910292675

Avkiran, N. K. (2006). Developing foreign bank efficiency models for DEA grounded in finance theory. Socio-Economic planning sciences, 40(4), 275-296. https://doi.org/10.1016/j.seps.2004.10.006

Avkiran, N. K. (2009). Opening the black box of efficiency analysis: an illustration with UAE banks, Omega, 37(4), 930-941. https://doi.org/10.1016/j.omega.2008.08.001

Avkiran, N. K. (2015). An illustration of dynamic network DEA in commercial banking including robustness tests. Omega, 55, 141-150. https://doi.org/10.1016/j.omega.2014.07.002

Bal, H., Örkcü, H. H., \& Çelebioğlu, S. (2010). Improving the discrimination power and weights dispersion in the data envelopment analysis. Computers \& Operations Research, 37(1), 99-107. https://doi.org/10.1016/j.cor.2009.03.028

Banker, R. D., Charnes, A., \& Cooper, W. W. (1984). Some models for estimating technical and scale inefficiencies in data envelopment analysis. Management Science, 30(9), 1078-1092. https://doi.org/10.1287/mnsc.30.9.1078

Barros, C. P., Chen, Z., Liang, Q. B., \& Peypoch, N. (2011). Technical efficiency in the Chinese banking sector. Economic Modelling, 28(5), 2083-2089. https://doi.org/10.1016/j.econmod.2011.04.003 
Berger, A. N. (2007). International comparisons of banking efficiency. Financial Markets, Institutions \& Instruments, 16(3), 119-144. https://doi.org/10.1111/j.1468-0416.2007.00121.x

Berger, A. N., \& Humphrey, D. B. (1997). Efficiency of financial institutions: International survey and directions for future research. European Journal of Operational Research, 98(2), 175-212. https://doi.org/10.1016/S0377-2217(96)00342-6

Bulajic, M., Jeremic, V., Knezevic, S., \& Zarkic-Joksimovic, N. (2013). A statistical approach to evaluating efficiency of banks. Economic Research-Ekonomska Istraživanja, 26(4), 91-100. https://doi.org/10.1080/1331677X.2013.11517632

Casu, B., Girardone, C., \& Molyneux, P. (2004). Productivity change in European banking: a comparison of parametric and non-parametric approaches. Journal of Banking \& Finance, 28(10), 25212540. https://doi.org/10.1016/j.jbankfin.2003.10.014

Charnes, A., Cooper, W. W., \& Rhodes, E. (1978). Measuring the efficiency of decision making units. European Journal of Operational Research, 2(6), 429-444. https://doi.org/10.1016/0377-2217(78)90138-8

Chiu, C. R., Chiu, Y. H., Fang, C. L., \& Pang, R. Z. (2014). The performance of commercial banks based on a context - dependent range - adjusted measure model, International Transactions in Operational Research, 21(5), 761-775. https://doi.org/10.1111/itor.12069

Cook, W. D., \& Zhu, J. (2008). CAR-DEA: context-dependent assurance regions in DEA. Operations Research, 56(1), 69-78. https://doi.org/10.1287/opre.1070.0500

Cooper, W. W., Seiford, L. M., \& Tone, K. (2006). Introduction to data envelopment analysis and its uses: with DEA-solver software and references. Springer Science \& Business Media.

Cvetkoska, V., \& Savić, G. (2017). Efficiency of bank branches: empirical evidence from a two-phase research approach. Economic Research-Ekonomska Istraživanja, 30(1), 318-333. https://doi.org/10.1080/1331677X.2017.1305775

Davison, A. C., \& Hinkley, D. V. (1997). Bootstrap methods and their application (Vol. 1). Cambridge university press. https://doi.org/10.1017/CBO9780511802843

Davutyan, N., \& Yildirim, C. (2017). Efficiency in Turkish banking: post-restructuring evidence. The European Journal of Finance, 23(2), 170-191. https://doi.org/10.1080/1351847X.2015.1049282

Delis, M., Iosifidi, M., \& Tsionas, M. G. (2017). Endogenous bank risk and efficiency. European Journal of Operational Research, 260(1), 376-387. https://doi.org/10.1016/j.ejor.2016.12.024

Devaney, M., \& Weber, W. L. (2002). Small-business lending and profit efficiency in commercial banking. Journal of Financial Services Research, 22(3), 225-246. https://doi.org/10.1023/A:1019733226515

Dobrota, M., Bulajic, M., Bornmann, L., \& Jeremic, V. (2016). A new approach to the QS university ranking using the composite I-distance indicator: uncertainty and sensitivity analyses. Journal of the Association for Information Science and Technology, 67(1), 200-211.

https://doi.org/10.1002/asi.23355

Dobrota, M., Martic, M., Bulajic, M., \& Jeremic, V. (2015). Two-phased composite I-distance indicator approach for evaluation of countries' information development. Telecommunications Policy, 39(5), 406-420. https://doi.org/10.1016/j.telpol.2015.03.003

Dyson, R. G., \& Thanassoulis, E. (1988). Reducing weight flexibility in data envelopment analysis. Journal of the Operational Research Society, 39(6), 563-576. https://doi.org/10.1057/jors.1988.96

Efron, B. (1979). Bootstrap methods: another look at the jackknife. The Annals of Statistics, 7(1), 1-26. https://doi.org/10.1214/aos/1176344552

Emrouznejad, A., Banker, R., Lopes, A. L., de Almeida, M. R. (2014). DEA in the public sector. Socioeconomic Planning Sciences, 48(1), 2-3. https://doi.org/10.1016/j.seps.2013.12.005

Emrouznejad, A., \& Yang, G. L. (2018). A survey and analysis of the first 40 years of scholarly literature in DEA: 1978-2016. Socio-Economic Planning Sciences, 61, 4-8.

https://doi.org/10.1016/j.seps.2017.01.008 
Eskelinen, J. (2017). Comparison of variable selection techniques for data envelopment analysis in a retail bank. European Journal of Operational Research, 259(2), 778-788.

https://doi.org/10.1016/j.ejor.2016.11.009

Färe, R., Grosskopf, S., Maudos, J., \& Tortosa-Ausina, E. (2015). Revisiting the quiet life hypothesis in banking using nonparametric techniques. Journal of Business Economics and Management, 16(1), 159-187. https://doi.org/10.3846/16111699.2012.726929

Ferrier, G. D., \& Hirschberg, J. G. (1997). Bootstrapping confidence intervals for linear programming efficiency scores: with an illustration using Italian banking data. Journal of Productivity Analysis, 8(1), 19-33. https://doi.org/10.1023/A:1007768229846

Fethi, M. D., \& Pasiouras, F. (2010). Assessing bank efficiency and performance with operational research and artificial intelligence techniques: a survey. European Journal of Operational Research, 204(2), 189-198. https://doi.org/10.1016/j.ejor.2009.08.003

Fukuyama, H., \& Matousek, R. (2017). Modelling bank performance: a network DEA approach. European Journal of Operational Research, 259(2), 721-732. https://doi.org/10.1016/j.ejor.2016.10.044

Fukuyama, H., \& Weber, W. L. (2002). Estimating output allocative efficiency and productivity change: application to Japanese banks. European Journal of Operational Research, 137(1), 177-190. https://doi.org/10.1016/S0377-2217(01)00054-6

Fukuyama, H., \& Weber, W. L. (2017). Japanese bank productivity, 2007-2012: a dynamic network approach. Pacific Economic Review, 22(4), 649-676. https://doi.org/10.1111/1468-0106.12199

Galagedera, D. U. (2014). Modeling risk concerns and returns preferences in performance appraisal: an application to global equity markets. Journal of International Financial Markets, Institutions and Money, 33, 400-416. https://doi.org/10.1016/j.intfin.2014.09.006

Gofman, M. (2017). Efficiency and stability of a financial architecture with too-interconnected-to-fail institutions. Journal of Financial Economics, 124(1), 113-146.

https://doi.org/10.1016/j.jfineco.2016.12.009

Gonçalves, A. C., Almeida, R. M., Lins, M. P. E., \& Samanez, C. P. (2013). Canonical correlation analysis in the definition of weight restrictions for data envelopment analysis. Journal of Applied Statistics, 40(5), 1032-1043. https://doi.org/10.1080/02664763.2013.772571

Hou, X., Wang, Q., \& Zhang, Q. (2014). Market structure, risk taking, and the efficiency of Chinese commercial banks. Emerging Markets Review, 20, 75-88. https://doi.org/10.1016/j.ememar.2014.06.001

Huang, T. H., Lin, C. I., \& Chen, K. C. (2017). Evaluating efficiencies of Chinese commercial banks in the context of stochastic multistage technologies. Pacific-Basin Finance Journal, 41, 93-110. https://doi.org/10.1016/j.pacfin.2016.12.008

Isik, I., \& Hassan, M. K. (2002). Technical, scale and allocative efficiencies of Turkish banking industry. Journal of Banking \& Finance, 26(4), 719-766. https://doi.org/10.1016/S0378-4266(01)00167-4

Išljamović, S., Jeremić, V., Petrović, N., \& Radojičić, Z. (2015). Colouring the socio-economic development into green: I-distance framework for countries' welfare evaluation. Quality \& Quantity, 49(2), 617-629. https://doi.org/10.1007/s11135-014-0012-0

Ivanovic, B. (1977). Classification theory. Institute for Industrial Economic, Belgrade.

Jain, V., Kumar, A., Kumar, S., \& Chandra, C. (2015). Weight restrictions in data envelopment analysis: a comprehensive genetic algorithm based approach for incorporating value judgments. Expert Systems with Applications, 42(3), 1503-1512.

Jayaraman, A. R., Srinivasan, M. R., \& Jeremic, V. (2013). Empirical analysis of banks in India using DBA and DEA. Management, 18(69), 25-35. https://doi.org/10.7595/management.fon.2013.0029

Jeremic, V., Bulajic, M., Martic, M., Markovic, A., Savic, G., Jeremic, D., \& Radojicic, Z. (2012). An evaluation of European countries' health systems through distance based analysis. Hippokratia, 16(2), 170-174. 
Jeremic, V., Bulajic, M., Martic, M., \& Radojicic, Z. (2011). A fresh approach to evaluating the academic ranking of world universities. Scientometrics, 87(3), 587-596. https://doi.org/10.1007/s11192-0110361-6

Johnes, J., Izzeldin, M., \& Pappas, V. (2014). A comparison of performance of Islamic and conventional banks 2004-2009. Journal of Economic Behavior \& Organization, 103, 93-107. https://doi.org/10.1016/j.jebo.2013.07.016

Kao, C., \& Liu, S. T. (2004). Predicting bank performance with financial forecasts: a case of Taiwan commercial banks. Journal of Banking \& Finance, 28(10), 2353-2368. https://doi.org/10.1016/j.jbankfin.2003.09.008

Kao, C., \& Liu, S. T. (2014). Multi-period efficiency measurement in data envelopment analysis: the case of Taiwanese commercial banks. Omega, 47, 90-98. https://doi.org/10.1016/j.omega.2013.09.001

Kao, C., \& Liu, S. T. (2016). A parallel production frontiers approach for intertemporal efficiency analysis: the case of Taiwanese commercial banks. European Journal of Operational Research, 255(2), 411-421. https://doi.org/10.1016/j.ejor.2016.04.047

Kevork, I. S., Pange, J., Tzeremes, P., \& Tzeremes, N. G. (2017). Estimating Malmquist productivity indexes using probabilistic directional distances: an application to the European banking sector. European Journal of Operational Research, 261(3), 1125-1140. https://doi.org/10.1016/j.ejor.2017.03.012

Kumar, M., Charles, V., \& Mishra, C. S. (2016). Evaluating the performance of indian banking sector using DEA during post-reform and global financial crisis. Journal of Business Economics and Management, 17(1), 156-172. https://doi.org/10.3846/16111699.2013.809785

Kuosmanen, T., \& Post, T. (2001). Measuring economic efficiency with incomplete price information: with an application to European commercial banks. European Journal of Operational Research, 134(1), 43-58. https://doi.org/10.1016/S0377-2217(00)00237-X

Le, P. T., Harvie, C., \& Arjomandi, A. (2017). Testing for differences in technical efficiency among groups within an industry. Applied Economics Letters, 24(3), 159-162. https://doi.org/10.1080/13504851.2016.1173172

Liu, J. S., Lu, L.Y., \& Lu, W. M. (2016). Research fronts in data envelopment analysis. Omega, 58, 33-45. https://doi.org/10.1016/j.omega.2015.04.004

Liu, J. S., Lu, L. Y., Lu, W. M., Lin, B. J. (2013). Data envelopment analysis 1978-2010: a citation-based literature survey. Omega, 41(1), 3-15. https://doi.org/10.1016/j.omega.2010.12.006

Mandic, K., Delibasic, B., Knezevic S., \& Benkovic, S. (2017). Analysis of the efficiency of insurance companies in Serbia using the fuzzy AHP and TOPSIS methods. Economic Research-Ekonomska Istraživanja, 30(1), 550-565. https://doi.org/10.1080/1331677X.2017.1305786

Marković, M., Knežević, S., Brown, A., \& Dmitrović, V. (2015). Measuring the productivity of Serbian banks using Malmquist index. Management: Journal of Sustainable Business and Management Solutions in Emerging Economies, 20(76), 1-10. https://doi.org/10.7595/management.fon.2015.0022

Mecit, E. D., \& Alp, I. (2013). A new proposed model of restricted data envelopment analysis by correlation coefficients. Applied Mathematical Modelling, 37(5), 3407-3425. https://doi.org/10.1016/j.apm.2012.07.010

Mihailović, N., Bulajić M., \& Savić, G. (2009). Ranking of banks in Serbia. Yugoslav Journal of Operations Research, 19(2), 323-334. https://doi.org/10.2298/YJOR0902323M

Moradi-Motlagh, A., \& Saleh, A. S. (2014). Re-examining the technical efficiency of Australian banks: a Bootstrap DEA Approach. Australian Economic Papers, 53(1-2), 112-128. https://doi.org/10.1111/1467-8454.12024

Mukherjee, A., Nath, P., \& Nath Pal, M. (2002). Performance benchmarking and strategic homogeneity of Indian banks. International Journal of Bank Marketing, 20(3), 122-139.

https://doi.org/10.1108/02652320210430965 
Nurboja, B., \& Košak, M. (2017). Banking efficiency in South East Europe: evidence for financial crises and the gap between new EU members and candidate countries. Economic Systems, 41(1), 122-138. https://doi.org/10.1016/j.ecosys.2016.05.006

Paradi, J. C., \& Zhu, H. (2013). A survey on bank branch efficiency and performance research with data envelopment analysis. Omega, 41(1), 61-79. https://doi.org/10.1016/j.omega.2011.08.010

Paul, S., \& Kourouche, K. (2008). Regulatory policy and the efficiency of the banking sector in Australia. Australian Economic Review, 41(3), 260-271. https://doi.org/10.1111/j.1467-8462.2008.00504.x

Podinovski, V. V. (2005). The explicit role of weight bounds in models of data envelopment analysis. Journal of the Operational Research Society, 56(12), 1408-1418. https://doi.org/10.1057/palgrave.jors.2601969

Podinovski, V. V. (2016). Optimal weights in DEA models with weight restrictions. European Journal of Operational Research, 254(3), 916-924. https://doi.org/10.1016/j.ejor.2016.04.035

Psillaki, M., \& Mamatzakis, E. (2017). What drives bank performance in transitions economies? The impact of reforms and regulations. Research in International Business and Finance, 39, 578-594. https://doi.org/10.1016/j.ribaf.2016.09.010

Puri, J., \& Yadav, S. P. (2013). A concept of fuzzy input mix-efficiency in fuzzy DEA and its application in banking sector. Expert Systems with Applications, 40(5), 1437-1450.

https://doi.org/10.1016/j.eswa.2012.08.047

Radojicic, M., Savic, G., Radovanovic, S., \& Jeremic, V. (2015, September). A novel bootstrap DBA-DEA approach in evaluating efficiency of banks. 12th Balkan Conference on Operational Research - BALCOR (pp. 375-384), Constanta, Romania.

Ray, S. C., \& Das, A. (2010). Distribution of cost and profit efficiency: evidence from Indian banking. European Journal of Operational Research, 201(1), 297-307. https://doi.org/10.1016/j.ejor.2009.02.030

Řepková, I. (2014). Efficiency of the Czech banking sector employing the DEA window analysis approach. Procedia Economics and Finance, 12, 587-596. https://doi.org/10.1016/S2212-5671(14)00383-9

Sahoo, B. K., \& Tone, K. (2009). Decomposing capacity utilization in data envelopment analysis: an application to banks in India. European Journal of Operational Research, 195(2), 575-594. https://doi.org/10.1016/j.ejor.2008.02.017

Sarrico, C. S., \& Dyson, R. G. (2004). Restricting virtual weights in data envelopment analysis. European Journal of Operational Research, 159(1), 17-34. https://doi.org/10.1016/S0377-2217(03)00402-8

Savic, G., Radosavljevic, M., \& Ilievski, D. (2012). DEA window analysis approach for measuring the efficiency of Serbian banks based on panel data. Management, 17(65), 5-14. https://doi.org/10.7595/management.fon.2012.0028

Scalzer, R. S., Rodrigues, A., Macedo, M. Á. D. S., \& Wanke, P. (2018). Insolvency of Brazilian electricity distributors: a DEA bootstrap approach. Technological and Economic Development of Economy, 24(2), 718-738. https://doi.org/10.3846/20294913.2017.1318312

Seifert, L. M., \& Zhu, J. (1998). Identifying excesses and deficits in Chinese industrial productivity (1953-1990): a weighted data envelopment analysis approach. Omega, 26(2), 279-296. https://doi.org/10.1016/S0305-0483(98)00011-5

Shang, J., \& Sueyoshi, T. (1995). A unified framework for the selection of a flexible manufacturing system. European Journal of Operational Research, 85(2), 297-315.

https://doi.org/10.1016/0377-2217(94)00041-A

Silva, T. C., Tabak, B. M., Cajueiro, D. O., Dias, M. V. B. (2017). A comparison of DEA and SFA using micro-and macro-level perspectives: efficiency of Chinese local banks. Physica A: Statistical Mechanics and its Applications, 469, 216-223. https://doi.org/10.1016/j.physa.2016.11.041

Simar, L. (2007). How to improve the performances of DEA/FDH estimators in the presence of noise?. Journal of Productivity Analysis, 28(3), 183-201. https://doi.org/10.1007/s11123-007-0057-3 
Simar, L., \& Wilson, P. W. (1998). Sensitivity analysis of efficiency scores: how to bootstrap in nonparametric frontier models. Management Science, 44(1), 49-61. https://doi.org/10.1287/mnsc.44.1.49

Simar, L., \& Wilson, P. W. (2007). Estimation and inference in two-stage, semi-parametric models of production processes. Journal of Econometrics, 136(1), 31-64. https://doi.org/10.1016/j.jeconom.2005.07.009

Simar, L., \& Zelenyuk, V. (2011). Stochastic FDH/DEA estimators for frontier analysis. Journal of Productivity Analysis, 36(1), 1-20. https://doi.org/10.1007/s11123-010-0170-6

Simper, R., Hall, M. J., Liu, W., Zelenyuk, V., \& Zhou, Z. (2017). How relevant is the choice of risk management control variable to non-parametric bank profit efficiency analysis? The case of South Korean banks. Annals of Operations Research, 250(1), 105-127. https://doi.org/10.1007/s10479-015-1946-X

Staub, R. B., Souza, G. D. S., \& Tabak, B. M. (2010). Evolution of bank efficiency in Brazil: A DEA approach. European Journal of Operational Research, 202(1), 204-213. https://doi.org/10.1016/j.ejor.2009.04.025

Stewart, C., Matousek, R., \& Nguyen, T. N. (2016). Efficiency in the Vietnamese banking system: a DEA double bootstrap approach. Research in International Business and Finance, 36, 96-111. https://doi.org/10.1016/j.ribaf.2015.09.006

Takamura, Y., \& Tone, K. (2003). A comparative site evaluation study for relocating Japanese government agencies out of Tokyo. Socio-Economic Planning Sciences, 37(2), 85-102. https://doi.org/10.1016/S0038-0121(02)00049-6

Tan, Y., Floros, C., \& Anchor, J. (2017). The profitability of Chinese banks: impacts of risk, competition and efficiency. Review of Accounting and Finance, 16(1), 86-105. https://doi.org/10.1108/RAF-05-2015-0072

Tandon, D., Tandon, K., \& Malhotra, N. (2014). An evaluation of the technical, pure technical and scale efficiencies in the Indian banking industry using data envelope analysis. Global Business Review, 15(3), 545-563. https://doi.org/10.1177/0972150914535141

Tanna, S., Luo, Y., \& De Vita, G. (2017). What is the net effect of financial liberalization on bank productivity? A decomposition analysis of bank total factor productivity growth. Journal of Financial Stability, 30, 67-78. https://doi.org/10.1016/j.jfs.2017.04.003

Taylor, W. M., Thompson, R. G., Thrall, R. M., \& Dharmapala, P. S. (1997). DEA/AR efficiency and profitability of Mexican banks a total income model. European Journal of Operational Research, 98(2), 346-363. https://doi.org/10.1016/S0377-2217(96)00352-9

Thanassoulis, E., Boussofiane, A., \& Dyson, R. G. (1995). Exploring output quality targets in the provision of perinatal care in England using data envelopment analysis. European Journal of Operational Research, 80(3), 588-607. https://doi.org/10.1016/0377-2217(94)00139-4

Thompson, R. G., Langemeier, L. N., Lee, C. T., Lee, E., \& Thrall, R. M. (1990). The role of multiplier bounds in efficiency analysis with application to Kansas farming. Journal of Econometrics, 46(1-2), 93-108. https://doi.org/10.1016/0304-4076(90)90049-Y

Thompson, R. G., Singleton Jr, F. D., Thrall, R. M., Smith, B. A. (1986). Comparative site evaluations for locating a high-energy physics lab in Texas. Interfaces, 16(6), 35-49. https://doi.org/10.1287/inte.16.6.35

Thoraneenitiyan, N., \& Avkiran, N. K. (2009). Measuring the impact of restructuring and countryspecific factors on the efficiency of post-crisis East Asian banking systems: integrating DEA with SFA. Socio-Economic Planning Sciences, 43(4), 240-252. https://doi.org/10.1016/j.seps.2008.12.002

Tortosa-Ausina, E., Grifell-Tatjé, E., Armero, C., \& Conesa, D. (2008). Sensitivity analysis of efficiency and Malmquist productivity indices: an application to Spanish savings banks. European Journal of Operational Research, 184(3), 1062-1084. https://doi.org/10.1016/j.ejor.2006.11.035 
Tsionas, E. G., \& Mamatzakis, E. C. (2017). Adjustment costs in the technical efficiency: an application to global banking. European Journal of Operational Research, 256(2), 640-649. https://doi.org/10.1016/j.ejor.2016.06.037

Wong, Y. H., \& Beasley, J. E. (1990). Restricting weight flexibility in data envelopment analysis. Journal of the Operational Research Society, 41(9), 829-835. https://doi.org/10.1057/jors.1990.120

Yu, M. M. (2012). An integration of the multi-component DEA and GAR models to the measurement of hotel performance. Current Issues in Tourism, 15(5), 461-476. https://doi.org/10.1080/13683500.2011.613985

Zelenyuk, N., \& Zelenyuk, V. (2014, December). Regional and ownership drivers of bank efficiency. 27th Australasian Finance and Banking Conference. Sydney, Australia.

Zhu, J. (1996). DEA/AR analysis of the 1988-1989 performance of the Nanjing textiles corporation. Annals of Operations Research, 66(5), 311-335. https://doi.org/10.1007/BF02188949 